\title{
Impact of Bukit Dua Belas rainforest transformation to oil palm plantation on phylogenetic of soil bacterial communities in Sarolangun, Jambi, Sumatra, Indonesia
}

\author{
MARINI WIJAYANTI ${ }^{1, \vartheta}$, ARIS TRI WAHYUDI ${ }^{2}$, MUNTI YUHANA ${ }^{3}$, MARTIN ENGELHAUPT ${ }^{4}$, \\ ANJA MERYANDINI ${ }^{2, v \vee}$ \\ ${ }^{1}$ Department of Aquaculture, Faculty of Agriculture, Universitas Sriwijaya. Jl. Palembang Prabumulih Km 32, Indralaya, Ogan Ilir 30862, South \\ Sumatra, Indonesia. Tel./fax.: +62-711-580059, `email: mariniwijayanti@fp.unsri.ac.id \\ ${ }^{2}$ Department of Biology, Faculty of Mathematics and Natural Sciences. Institut Pertanian Bogor. Jl. Raya Dramaga, Bogor 16680, West Java, \\ Indonesia."vemail: ameryandini@yahoo.com \\ ${ }^{3}$ Department of Aquaculture, Faculty of Fisheries and Marine Sciences, Institut Pertanian Bogor. Jl. Raya Dramaga, Bogor 16680, West Java, Indonesia \\ ${ }^{4}$ Göttingen Genomics Laboratory, George August University Göttingen, Göttingen, Germany
}

Manuscript received: 3 October 2018. Revision accepted: 25 February 2019.

\begin{abstract}
Wijayanti M, Wahyudi AT, Yuhana M, Engelhaupt M, Meryandini A. 2019. Impact of Bukit Dua Belas rainforest transformation to oil palm plantation on phylogenetic of soil bacterial communities in Sarolangun, Jambi, Sumatra, Indonesia. Biodiversitas 20: 811-818. Land use change from forest to oil palm plantation at Sumatra could decrease biodiversity, including bacterial diversity. The case of Bukit Dua Belas transformation from forest to oil palm plantation was gotten for measuring shift community of soil bacterial in both areas. The diversity of bacterial communities from rainforest and oil palm plantation topsoil in Sumatra was studied using pyrosequencing of $16 \mathrm{~S}$ rRNA gene and common biodiversity indices. Phylogenetic approach was used to reveal the community shift of bacterial phyla and genera in both areas. Ecological approach was carried out by measuring soil $\mathrm{pH}$, TC (total carbon), TN (total nitrogen), AP (available phosphorous), bacterial diversity with Shannon and Simpson indices, and bacterial richness with Chao1-ACE index and OTUs. Bacterial diversity and richness on lowland forest topsoil and oil palm plantation soil were not different, as soil $\mathrm{pH}, \mathrm{TC}$, and $\mathrm{TN}$ as substrate factors were not different significantly. The majority of sequences related to Acidobacteria $(56.33 \%)$, Proteobacteria $(27.43 \%)$, Actinobacteria $(7.11 \%)$, and Cyanobacteria $(5.55 \%)$ were from forest; whereas those related to Acidobacteria (50.11\%), Proteobacteria (31.63\%), Actinobacteria (7.58\%), Chloroflexi (2.60\%), and Gemmatimonadetes $(2.71 \%)$ invented from oil palm plantation. Acidobacteria was the most dominant phyla in both habitats, because soil $\mathrm{pH}$ in both areas was acidic $\left(3.77-4.80 \mathrm{pH}_{\mathrm{H} 2 \mathrm{O}}\right)$. The genera of alpha-proteobacteria dominated in genera phylotype of bacterial 16S rRNA phylogenetic revealed in both forest and oil palm plantation topsoil. The most genera in phylogenetic tree are Burkholderia from Beta-proteobacteria. The bacterial community shift occurred in forest transformation, even though the oil palm plantation showed more bacterial phyla and genera than the lowland rainforest.
\end{abstract}

Keywords: Bacterial communities, Bukit Dua Belas rainforest, oil palm plantation, Sumatra

\section{INTRODUCTION}

Indonesia is one of Southeast Asia countries which has large biodiversity. Land use changes, especially deforestation and agricultural intensification were accused as factors affecting the decline of above-ground biodiversity. The highest deforestation rate for conversion of land to oil palm plantation has impacted its rich biodiversity. It has even more negative impacts for environment (Tripathi et al. 2012). Loss of environmental services provided by forests is a non-linear process in Jambi, Sumatra, Indonesia. A gradual simplification of complex agro-ecosystems of agro-forestry with increasing profitability might be threatened by the oil palm plantation industry (Mudiyarso et al. 2002).

The tropical lowland forests are ecosystems that are rich in endemic species of flora, fauna, and microbes such as prokaryotes, bacteria. Lee-Cruz et al. (2013) reported that bacteria were grouped into operational taxonomic units (OTUs) at the 97\% similarity level, and OTU richness and local-scale diversity showed no difference between the various forest types and oil palm plantations (Lee-Cruz et al. 2013). Forest clearance for oil palm plantation significantly impacts the composition of soil bacterial communities, revealing in the loss of some forest bacterial population, whereas primary and logged forests have not been different in its composition. The soil bacteria of tropical forest are to some extent flexible or resistant to logging, but the impacts of forest conversion to oil palm plantation are more severe for the loss of bacterial diversity (Lee-Cruz et al. 2013).

Bacterial composition and diversity were affected by soil properties, mainly $\mathrm{pH}$, total carbon, and $\mathrm{C} / \mathrm{N}$ ratio of soil. The $\mathrm{pH}$ value of soil is the most affecting factor of bacterial community composition and diversity among other soil properties and various landuse types. The highest diversity of soil bacteria occurs on soil with neutral $\mathrm{pH}$. The variation in phylogenetic structure of dominant taxa (Proteobacteria, Acidobacteria, and Actinobacteria) is also significantly correlated with $\mathrm{pH}$ value of soil. The diversity 
of soil bacteria in oil palm plantation is higher than primary forest, because the soil $\mathrm{pH}$ in forest is lower than oil palm plantation (Tripathi et al. 2012). Among the most abundant operational taxonomic units (OTUs), there was clear evidence of niche partitioning by $\mathrm{pH}$ value. The $\mathrm{pH}$ value plays a major role in structuring tropical soil bacterial communities. Soil $\mathrm{pH}$ was the best forecaster of diversity and community composition of bacteria (Tripathi et al. 2013). The distribution of some bacterial groups and subgroups in different sites correlated with soil properties and vegetation. Soil organic matter (SOM), total nitrogen (TN), and specific plant group were important factors shaping the composition of bacterial communities ( $\mathrm{Li}$ et al. 2014). Tsiknia et al. (2014) predicted that $31-79 \%$ of the spatial variation in microbial taxa abundance could be explained by the parameters measured, with total organic carbon and $\mathrm{pH}$ being identified as the most important. In this study, we described the diversity of soil bacteria from low land forest and oil palm plantation (transformation area). We used molecular phylogenetic approaches for analyzing community shift of bacteria between both areas.

\section{MATERIALS AND METHODS}

\section{Soil sampling}

Soil samples used for this study were the topsoils collected from lowland forest in Bukit Dua Belas National Park and an oil palm plantation in Sarolangun District, Jambi Province, Sumatra, Indonesia (between $102^{\circ} 32^{\prime} 00^{\prime \prime}-102^{\circ} 45^{\prime} 00^{\prime \prime}$ East and 1 ${ }^{\circ} 55^{\prime} 0 "-2^{\circ} 5^{\prime} 0^{\prime \prime}$ South).

The notations used on the samples were BF1, BF3, and $\mathrm{BF} 4$ for the lowland forest area, and $\mathrm{BO} 2, \mathrm{BO} 3$, and $\mathrm{BO} 4$ for the oil palm plantation area. In each of these six subareas, small cores were collected in five replicates and triplicates of each core (approximately 10 grams) from topsoil and surface sediment (approximately $5 \mathrm{~cm}$ from the top), using a small shovel and tube (approximately 2 inches in diameter) respectively. The samples have been maintained at $\pm-40^{\circ} \mathrm{C}$. Samples from the same area were combined and mixed completely to produce one homogeneous sample. This study was conducted at Laboratory of Microbiology, Faculty of Mathematics and Natural Science, Bogor Agricultural University, Indonesia and Göttingen Genomics Laboratory, George August University of Göttingen, Germany.

Acidity of soil was in situ measured with a $\mathrm{pH}$ meter. All chemical parameters of soil (acidity, carbon, total nitrogen, and available phosphorous) were determined according to ISRIC standards (Van Reeuwijk 2000) at the Soil Research Institute, Bogor, Indonesia. All samples were kept on ice up to arrival at the laboratory and then were stored at $0-4^{\circ} \mathrm{C}$. Samples from the same area were combined and mixed completely to produce one homogeneous sample.

\section{DNA extraction from soil}

Total microbial community DNA was isolated from 10 $\mathrm{g}$ of soil per sample. For this purpose, the Mo BioPower Soil DNA extraction kit (Mo Bio Laboratories, Carlsbad,
CA) was used according to the instructions of the manufacturer (Ettenauer et al. 2012). The concentration and quality of the DNA preparations were estimated by a NanoDrop spectrophotometer and by electrophoresis on $0.8 \%$ agarose gels. Measurements were assessed using a NanoDrop® ND-1000 spectrophotometer (peqLab Biotechnologie $\mathrm{GmbH}$, Linz, Austria). They were used for the electrophoresis and the PCR amplification.

\section{PCR preparation for 454-Pyrosequencing}

Bacterial 16S rRNA genes were amplified by PCR using the forward primer $343 \mathrm{~F}$ (5'TACGGRAGGCAGCAG-3') and the reverse primer 909R (5'- CCGTCAATTCMTTTGAGT -3') (Liu et al. 2007; Wang et al. 2007). The PCR products were confirmed by subjecting $2 \mu \mathrm{L}$ of each sample to electrophoresis on a $0.8 \%$ agarose gel. The PCRs were carried out in triplicate with $50 \mu \mathrm{L}$ of the reaction mixture comprising $10 \mu \mathrm{L}$ of 10 fold Phusion buffer, $1 \mu \mathrm{L}$ of $10 \mathrm{mM}$ dNTPs, $1 \mu \mathrm{L}$ of each primer (1: 10), $2-5 \mu \mathrm{L}$ of diluted DNA sample, $0.5 \mu \mathrm{L}$ of Phusion HS DNA Polymerase $(2 \mathrm{U} / \mu \mathrm{L})$, and approximately $10 \mathrm{ng}$ of DNA template by using the programmable thermocycler (MJ Research PTC-200 Peltier Thermal Cycler, MJ Research, Inc., Malham, USA). The amplification program consisted of an initial denaturation step at $98^{\circ} \mathrm{C}$ for $5 \mathrm{~min}$, followed by 25 cycles of denaturation at $98^{\circ} \mathrm{C}$ for $45 \mathrm{sec}$, annealing at $55-68^{\circ} \mathrm{C}$ for $45 \mathrm{sec}$, and elongation at $72^{\circ} \mathrm{C}$ for $30 \mathrm{sec}$, with a final extension step at $72^{\circ} \mathrm{C}$ for $5 \mathrm{~min}$. The replicate PCR products of the same soil treating group were assembled within a PCR tube. The PCR products were visualized on agarose gels $(0.8 \%$ in TAE buffer) containing ethidium bromide, and purified using a peqGOLD Gel Extraction Kit (PEQLAB Biotechnologie GmbH, Erlangen, Germany). In general, gel extraction was performed according to manufacturer's instruction. Quantification of the PCR products was performed by using the Quant-iT dsDNA BR assay kit and a Qubit fluorometer (Invitrogen $\mathrm{GmbH}$, Karlsruhe, Germany) as recommended by the manufacturer. The Göttingen Genomics Laboratory determined the sequences of the partial 16S rRNA genes by employing the Roche GS-FLX 454 pyrosequencer (Roche, Mannheim, Germany) and using picotiter sequencing plates subdivided into 8 parts (1 part per sample). Amplicons were sequenced as recommended in the instructions of the manufacturer for amplicon sequencing (Will et al. 2010).

The quality filtering options were set if sequences that were too short (less than 250 base pair) or too long (more than 1000 base pairs), or have more than 8 bases of the same base in a row, they had been filtered out of the total data set. The further step for processing the sequence data was then clustering the sequences into Operational Taxonomic Units (OTUs). The grouping was based on sequence similarity of $99 \%$. This taxonomic assignment was made by using a database which includes huge amount of already known 16S rRNA sequences. The database used for the taxonomic assignment was the SILVA SSURef NR 111 database (www.arb-silva.de) (Quast et al. 2012). Rare faction curves were calculated as well as the Shannon and Simpson index based on OTU picker data, by employing 
the RDP pyrosequencing pipeline (Simpson 1949; Maguran 2004; Cole et al. 2009). ACE and Chao1 indices (abundance-based coverage estimator (ACE), biascorrected Chao1) (Chao and Bunge 2002) were calculated using the Estimate $\mathrm{S}$ program version 8.2.0 (http: //purl.oclc.org/estimates).

\section{RESULTS AND DISCUSSION}

\section{Effect of soil properties on bacterial diversity indices}

The compositions of soil bacterial communities present in two different soil systems derived from a forest site (further coded as BF) and an oil palm plantation site (coded as BO) were assessed and compared using pyrosequencingbased analysis of $16 \mathrm{~S}$ rRNA gene sequences. They could be influenced by soil chemical properties of samples from different land use types, the forest and oil palm plantation sites such as soil $\mathrm{pH}$, total carbon (TC), total nitrogen (TN), available phosphorus (AP), and $\mathrm{C} / \mathrm{N}$ ratio (Table 1 ). The ttest of two analyzed soil areas showed no significant differences in some soil parameters $(\mathrm{pH}, \mathrm{TC}, \mathrm{TN}$, and $\mathrm{C} / \mathrm{N}$ ratio), but significant differences in $\mathrm{AP}$ and $\mathrm{C} / \mathrm{N} / \mathrm{P}$ ratio. The AP content of the soil of site $\mathrm{BO}(0.42 \%)$ was higher than that of site $\mathrm{BF}(0.02 \%)$, the $\mathrm{C} / \mathrm{N} / \mathrm{P}$ ratio of site $\mathrm{BF}$ (653.4) was higher than that of site BO (32.7). AP varied significantly between forest and non-forest sites, while soil $\mathrm{pH}, \mathrm{TC}, \mathrm{TN}$, and $\mathrm{C} / \mathrm{N}$ ratio did not vary significantly across the landscape.

Forest conversion for agriculture drives changes in the soil chemistry. They can alter the $\mathrm{pH}$ value, lead to the loss of soil carbon, and modify the $\mathrm{C} / \mathrm{N}$ ratio and the concentration of phosphorous. Soil $\mathrm{pH}$ was found to be the best predictor of bacterial community across forest and plantation area (Tripathi et al. 2012). Soil pH in both areas were no significant differences, although soil $\mathrm{pH}$ of $\mathrm{BO}$ sample was relatively higher than that of BF sample. This condition could be considered as liming on the plantation sites under highly acidic soil conditions represented by ultisols, which constitute the most important soils for oil palm grown in tropical Asia, such as Indonesia. Increasing rates of dolomite and $\mathrm{MgCO}_{3}$ were found to reduce phytotoxic concentrations and activities of $\mathrm{Al}$ species and Mn in highly acidic soils (Cristancho et al. 2014).

Total carbon and $\mathrm{C} / \mathrm{N}$ ratio were lower in oil palm soils than in forests, suggesting that in this case other factors that impact on acid specific bacteria, such as $\mathrm{pH}$, had a stronger role than any effect the carbon concentration and $\mathrm{C} / \mathrm{N}$ ratio might have had on the copiotropic bacteria, like as Proteobacteria (Lee Cruz et al. 2013). Oil palm plantation had been applying inorganic fertilizer (agricultural lime and phosphorous fertilizer) for agricultural management. They increased the soil $\mathrm{pH}$ even though there were no significant differences between both areas. Based on Tropical Soil Quality Index (TSQI), TC (3.93 and 2.91\%) and $\mathrm{TN}(0.27$ and $0.22 \%)$ in both sites $\mathrm{BF}$ and $\mathrm{BO}$ were within range of moderate-adequate levels, but AP $(0.02 \%$ and $0.42 \%$ ) in both sites were considered high-excellent range that reserve of AP in slightly acidic to alkaline soils, possible adverse effects to water quality from erosion of high $\mathrm{P}$ soils (Arifin et al. 2012). Although abundant in soils, its availability is restricted as it occurs mostly in insoluble forms. A substantial number of bacterial species exhibit $\mathrm{P}$ solubilization capacity. Available $\mathrm{P}$ in $\mathrm{BO}$ area could improve the nutrient quantity of soil bacteria in oil palm plantation. They impacted to increase the diversity and abundances of soil bacteria in $\mathrm{BO}$ area rather than that in BF area. The phosphorous solubilizing bacteria activity had caused decreasing soil $\mathrm{pH}$ in the forest and the oil palm plantation (3.77 and 4.80). Soil pH considered the bacterial community composition and diversity across the various land use types, with the highest diversity close to neutral $\mathrm{pH}$ values (Tripathi et al. 2012). Soil $\mathrm{pH}$ in this study for both areas was acidic, so that impacted to increase acidic bacteria composition.

Table 1. Mean values ( \pm standard deviation) of soil parameters for soil samples from the forest site (BF) and the oil palm plantation site (BO)

\begin{tabular}{lccccccc}
\hline Sample sites & $\mathbf{p H}\left(\mathbf{H}_{\mathbf{2}} \mathbf{O}\right)$ & $\mathbf{p H}(\mathbf{K C l})$ & \multirow{2}{*}{ TC $(\boldsymbol{\%})$} & $\mathbf{T N}(\boldsymbol{\%})$ & $\mathbf{A P}(\boldsymbol{\%})$ & C/N ratio & C/N/P ratio \\
\hline $\mathrm{BF}$ & $3.77 \pm 0.31$ & $3.13 \pm 0.47$ & $3.93 \pm 1.83$ & $0.27 \pm 0.06$ & $0.02 \pm 0.00$ & $14.08 \pm 3.50$ & $653.4 \pm 90.5$ \\
$\mathrm{BO}$ & $4.80 \pm 0.79$ & $4.43 \pm 0.93$ & $2.91 \pm 0.86$ & $0.22 \pm 0.05$ & $0.42 \pm 0.13$ & $13.15 \pm 1.83$ & $32.7 \pm 11.4$ \\
\hline
\end{tabular}

Note: TC: Total Carbon; TN: Total Nitrogen; AP: Available Phosphorous; C: Carbon; N: Nitrogen; P: Phosphorous
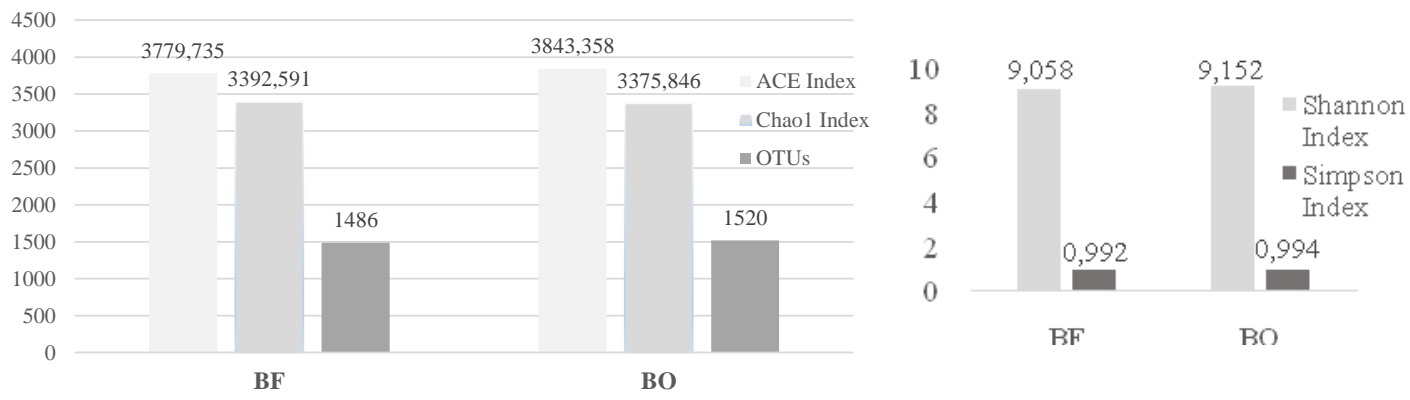

Figure 1. Bacterial richness indices of aggregates and whole soil at a genetic distance of $1 \%$, expressed as the number of observed unique OTUs, ACE, Chao1, Shannon Index, and Simpson Index 


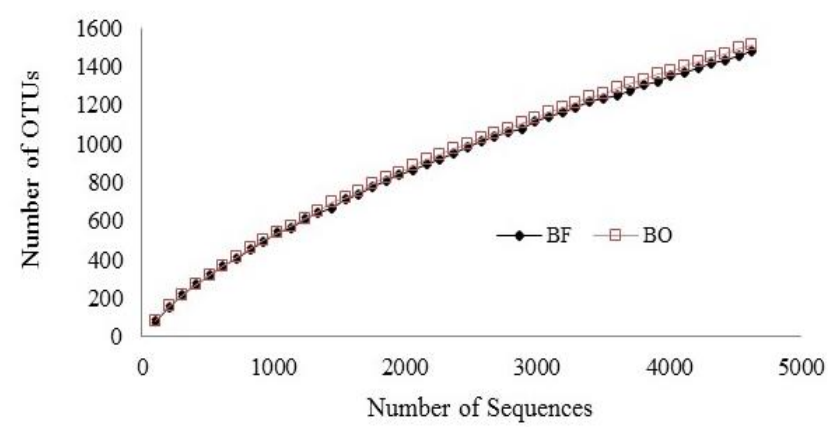

Figure 2. Rarefaction curves showing the observed number of operational taxonomic units (OTUs) at 1\% dissimilarity for samples from sites $\mathrm{BF}$ and $\mathrm{BO}$

The higher OTUs and Shannon indices observed in this study demonstrated the usefulness of pyrosequencing analysis in revealing the bacterial diversity and richness from the tropical low land rainforest and the oil palm plantation as deforestation area. Libraries of sites BF and BO were composed of 1486 and 1520 OTUs, respectively (Figure 1). Rarefaction curves were generated at $1 \%$ cut off to make a comparison of species richness between the two soil groups (Figure 2).

Based on Abundance-based Coverage Estimator (ACE) of both bacterial richness from site BF displayed relatively lower species richness than that from site BO, but based on Chao1 index, that from site BF displayed relatively higher than from site BO. Figure 1 showed similar comparative values with regard to the diversity for the two sample groups, with higher level of diversities observed for samples from site BO. When the genetic distances were 0.01, the value of ACE, Chaoland OTU for samples from site BF was 3779, 3392, and 1486, whereas that for samples from site BO was 3843, 3375, and 1520, respectively. Both the Shannon and Simpson diversity indices revealed similar trends, with lower values observed for samples from site BF (9.058 and 0.992), when compared with those from site BO (9.152 and 0.994) relatively, but they did not differ considerably. It was confirming the similarity of bacterial richness and diversity in both sites.

Similarly, the bacterial diversity was observed between the two sites, BF and BO, suggesting that these two soil systems are not different with diverse soil properties. The data obtained clearly demonstrated that the population of bacteria isolated from soils of site BF had slight lower diversity when compared with that from soils of site BO. The slight differences in the soil bacterial diversity might be explained by the slight differences in the concentration of TC and TN. Previous studies have shown that TC, TN, $\mathrm{AP}$, and $\mathrm{pH}$ are important regulators of soil microbial community composition and activities in the tropical forest and various land use type of agriculture area, included oil palm plantation area (Lee Cruz et al. 2013; Tripathi et al. 2013). In this study, similarity of bacterial OTUs and their richness and diversity showed that short term amendment of oil palm plantation, about eight up to ten years, have not made considerable difference of implication in their soil nutrient quality.

\section{Bacterial community composition in forest and oil palm plantation soils}

The 2457 classifiable sequences were affiliated with 23 phyla across the entire data set. The major phylum groups were those with a relative abundance of $>2 \%$. Figure 3 shows the phylum compositions of the two soil groups.

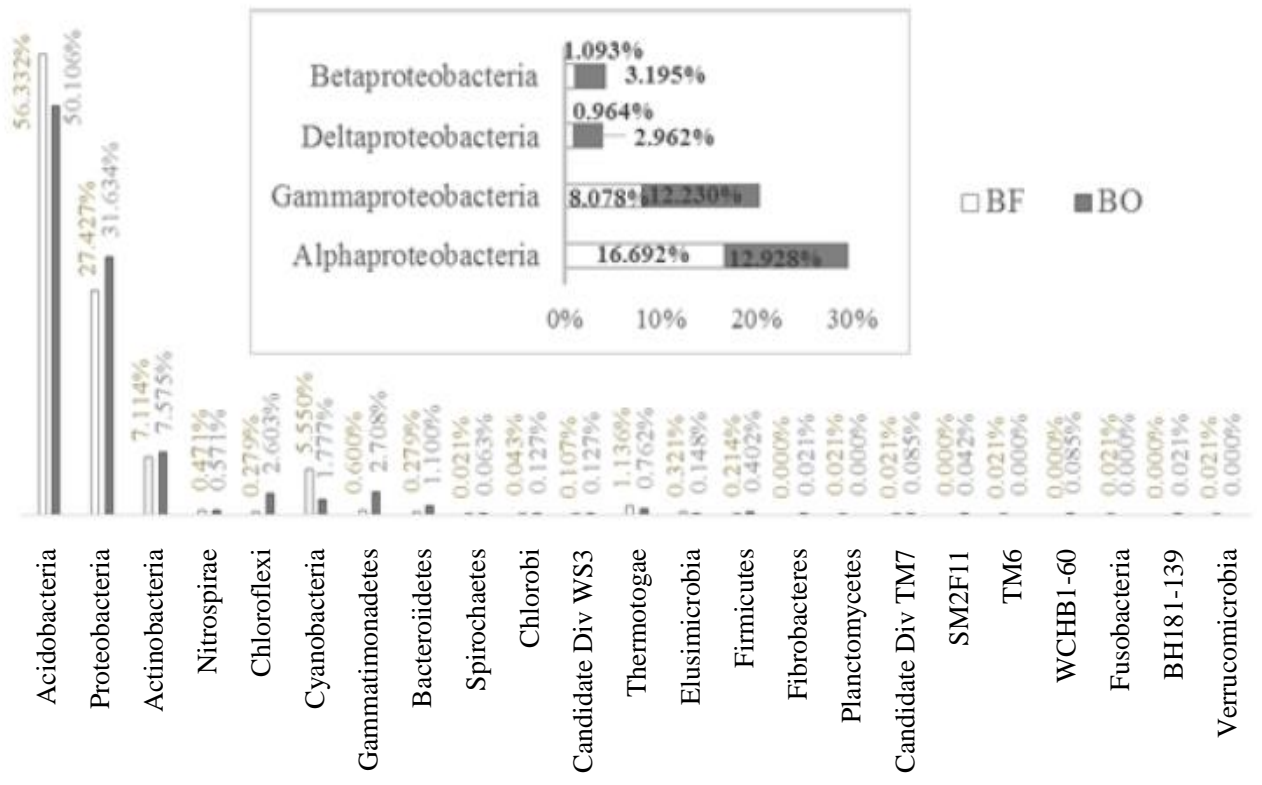

Figure 3. Average relative abundances of dominant bacterial taxa in samples collected in forest (BF) and oil palm plantation (BO) area 
Site BF was mainly composed of Acidobacteria (56.33\%), Proteobacteria (27.43\%), Actinobacteria (7.11\%), and Cyanobacteria (5.55\%). Site BO mostly comprised Acidobacteria $(50.11 \%)$, Proteobacteria (31.63\%), Actinobacteria (7.58\%), Chloroflexi (2.60\%), and Gemmatimonadetes (2.71\%). Acidobacteria contributed to the majority of the community composition of both soil groups, indicating that sequences associated with Acidobacteria contributed to the highest percentage of community DNA.

The prokaryote dominant from both of two areas were Acidobacteria. These phyla are oligotrophic organisms abundant in carbon-poor soils. The relative abundances of Actinobacteria, Alphaproteobacteria, and Gammaproteobacteria were positively correlated with soil $\mathrm{N}$ and $\mathrm{C}$ content, while acidobacterial relative abundance was correlated with $\mathrm{pH}$ factors. Secondary forest soils had lower $\mathrm{pH}(3.77 \pm 0.31)$ than oil palm plantation soils $(4.80$ \pm 0.79), probably promoting Acidobacterial abundance. Although the carbon content in oil palm plantation soils was lower than in forests, $\mathrm{pH}$ value in forest soil was lower than in oil palm plantation. Acidobacteria is strongly influenced by $\mathrm{pH}$, favoring soils with $\mathrm{pH}$ of 4 (Lee Cruz et al. 2013).

Proteobacteria as copiotrophic bacteria phylum had different composition of classes between both areas BF and BO. Alphaproteobacteria were found higher in BF area than BO area, while Beta-, Gamma-, Delta-proteobacteria were more abundant in $\mathrm{BO}$ than $\mathrm{BF}$ area. The Betaproteobacteria exhibited copiotrophic characteristic, their relative abundances were highest in soils with high $\mathrm{C}$ availability either as an essential element of the soil. The relative abundances of Acidobacteria decreased while the relative abundances of Betaproteobacteria and Bacteroidetes increased (Fierer et al. 2007). The Actinobacteria showed an increased abundance in oil palm plantations compared to forests (Lee Cruz et al. 2013). Existence of Actinobacteria in forest and oil palm plantation had been influenced by anthropogenic $\mathrm{N}$ through fertilization. Eisenlord and Zak (2010) concluded that changes in actinobacterial community composition may basis of biogeochemical responses to experimental $\mathrm{N}$ deposition in forest soil.

\section{Phylogenetical approach of bacterial community for forest and oil palm plantation sites}

16S rRNA-based phylogeny showing representatives of all bacterial phyla from tropical low land secondary forest (Figure 4) and oil palm plantation (Figure 5) soil derived sequences have been obtained. Fifteen phyla of bacteria were found in site $\mathrm{BF}$, while eighteen phyla of bacteria were found in site BO. More phyla in BO showed that bacterial diversity in $\mathrm{BO}$ was higher than those in $\mathrm{BF}$.

Although Acidobacteria were found as the highest abundance in forest and oil palm plantation area, Proteobacteria occupied the highest genera of bacterial community composition in both two areas (Figure 4 and Figure 5). Alpha-proteobacteria has more genera than others proteobacteria. Alpha-proteobacteria inhabited second highest phyla of bacterial community composition in surface and subsurface peat after the Acidobacteria (Serkebaeva et al. 2013). Similarity of acidic soil in peat and both two study areas (low land forest and oil palm plantation areas) might have impacted to similarity of highest phyla of bacterial community composition at representative sequences of genera in both two areas. Alpha-proteobacteria is the most abundant class, relative to total sequences, comprising $35-58 \%$ of Proteobacteria, but the most abundant orders contained no cultivated and became more dominant at intermediate $\mathrm{pH}$ (Spain et al. 2009; Griffiths et al. 2011). This class had more genera than others because of their capability to survive in acidic soil and degrade herbicide (Liu et al. 2011). Oil palm plantation soil contained herbicide for treating unwanted vegetation surrounding areas.

The highest genera in phylogenetic trees (Figure 4 and 5 ) is Burkholderia. Burkholderia genera were found 9 phylotypes from 18 Burkholderiales in forest and 14 phylotypes from 37 Burkholderiales in oil palm plantation. These genera in $\mathrm{BO}$ were more variated than genera in BF. In the sites, genera of Burkholderia were the most population of bacterial isolates from forest and oil palm plantation soil (Wijayanti et al. 2014). In the acidic forest soil, most of Al-resistant bacteria were assigned to the genus Burkholderia and few of them were assigned to the genus Acinetobacter (Kunito et al. 2012).

The most of genus Burkholderia was reliable with the identification as an acid tolerant bacteria. They may outcompete other taxa in acidic soil. Burkholderia has developed $\mathrm{pH}$ tolerance mechanisms to survive and grow in environmental niches where many other taxa are inhibited. Their capability for acid tolerant was approach for tolerance to heavy metal stress factors and to biological controls in competing with fungi (Stopnisek et al. 2013). In oil palm plantation area, genus Burkholderia reached the highest phylotype of genera in this study. The genera are included in beta proteobacteria. Strains of the genus Burkholderia occupy a wide range of ecological niches and have versatile properties of bioremediation, bio-control, and plant growth promotion (Coenye and Vandamme 2003). It has many potentials for sustainable agriculture development.

In conclusion, bacterial diversity and richness in lowland forest and oil palm plantation soil were not different if soil $\mathrm{pH}, \mathrm{TC}$, and $\mathrm{TN}$ as substrate factors were not different significantly. Acidobacteria was the most dominated phyla in both areas, because soil $\mathrm{pH}$ in both areas was acidic. The genera of alpha-proteobacteria dominated in genera phylotype of bacterial 16S rRNA phylogenetic revealed in both soil forest and plantation. The bacterial shift community was occurred in forest transformation, even though the oil palm plantation had more phyla and genera of bacteria than the lowland forest. It was caused by plantation management of oil palm plantation sites. 


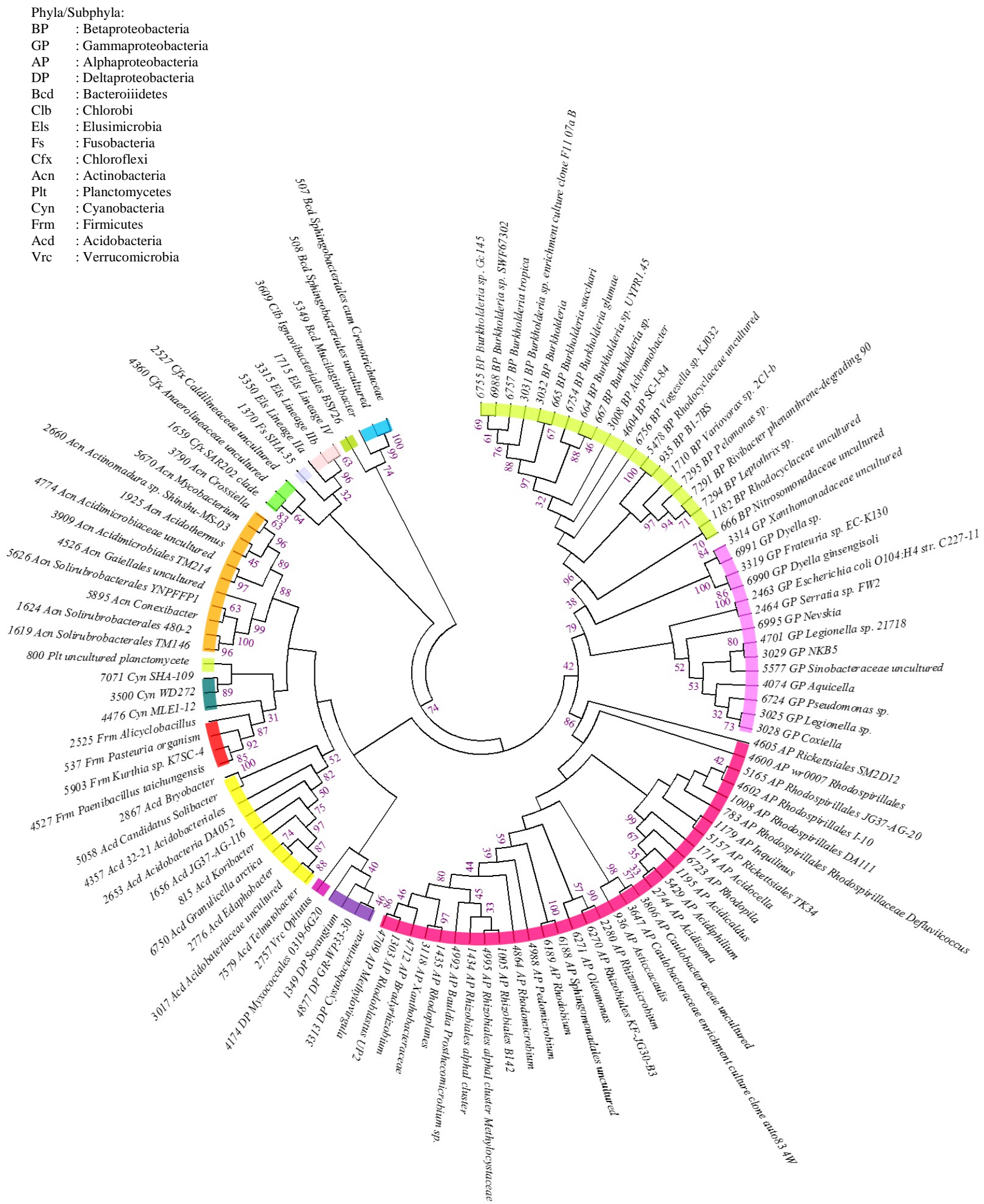

Figure 4. 16S rRNA-based phylogeny showing representatives of all bacterial phyla from tropical low land secondary forest soil (site BF) derived sequences have been obtained. Note: Molecular Phylogenetic analysis by Maximum Likelihood method. The evolutionary history was inferred by using the Maximum Likelihood method based on the Kimura 2-parameter model (Kimura 1980). The tree with the highest log likelihood (-13181.3047) is shown. Initial tree (s) for the heuristic search were obtained by applying the NeighborJoining method to a matrix of pairwise distances estimated using the Maximum Composite Likelihood (MCL) approach. There were a total of 394 positions in the final dataset. Evolutionary analyses were conducted in MEGA6 (Tamura et al. 2013). Bootstrap values (calculated from 1000 replicates) $>30$ are shown. 


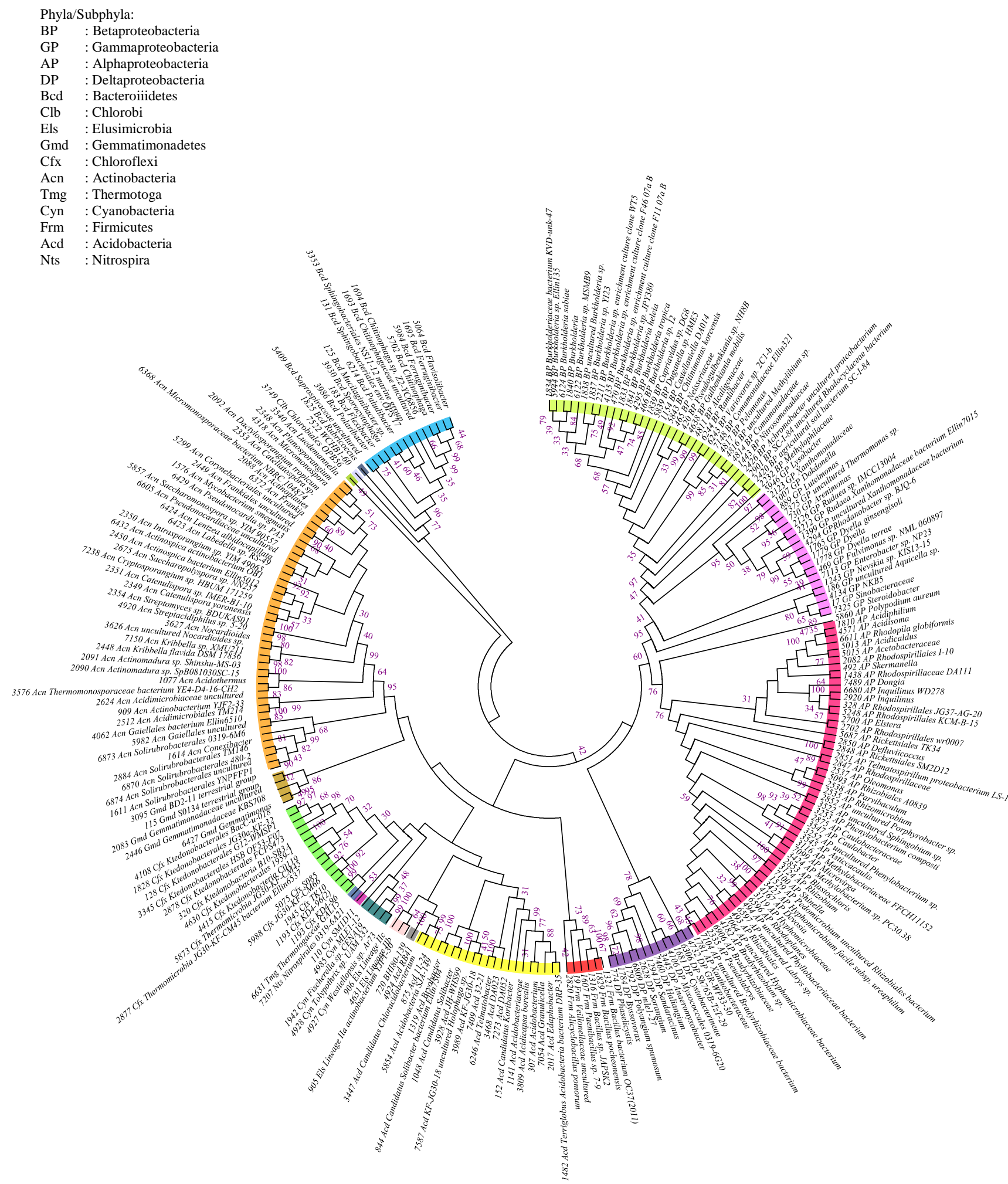

Figure 5. 16S rRNA-based phylogeny showing representatives of all bacterial phyla from oil palm plantation soil (site BO) derived sequences have been obtained. Note: Molecular Phylogenetic analysis by Maximum Likelihood method The evolutionary history was inferred by using the Maximum Likelihood method based on the Kimura 2-parameter model (Kimura 1980). The tree with the highest $\log$ likelihood (-26568.1997) is shown. The percentage of trees in which the associated taxa clustered together is shown next to the branches. Initial tree (s) for the heuristic search were obtained by applying the Neighbor-Joining method to a matrix of pairwise distances estimated using the Maximum Composite Likelihood (MCL) approach. There were a total of 457 positions in the final dataset. Evolutionary analyses were conducted in MEGA6 (Tamura et al. 2013). Bootstrap values (calculated from 1000 replicates) >30 are shown 


\section{ACKNOWLEDGEMENTS}

This research was supported by the Ministry of Research, Technology, and Higher Education of the Republic of Indonesia for a doctoral scholarship program (from Sriwijaya University, Indonesia) and by CRC 990 EFForTS Bogor Agricultural University, Indonesia. We would like to extend our gratitude to Prof. Rolf Daniel and Martin Engelhaupt (R.I.P.) for facilitating the molecular work at the Genomic Laboratory at George-August University, Göttingen, Germany.

\section{REFERENCES}

Arifin A, Karam DS, Shamshuddin J, Majid NM, Radziah O, Hazandy AH, Hazari H. 2012. Proposing a suitable soil quality index for natural, secondary and rehabilitated tropical forests in Malaysia. Afr J Biotechnol 11 (14): 3297-3309.

Chao A, Bunge J. 2002. Estimating the number of species in a stochastic abundance model. Biometric 58: 531- 539.

Coenye T, Vandamme P. 2003. Diversity and significance of Burkholderia species occupying diverse ecological niches. Environ Microbiol 5 (9): 719-729.

Cole JR, Wang Q, Cardenas E, Fish J, Chai B, Farris RJ, Kulam-SyedMohideen AS, McGarrell DM, Marsh T, Garrity GM, and Tiedje JM. 2009. The ribosomal database project: improved alignments and new tools for rRNA analysis. Nucleic Acids Res 37: 141-145.

Cristancho RJA, Hanafi MM, Omar SRS, Rafii MY. 2014. Aluminum speciation of amended acid tropical soil and its effects on plant root growth. J Plant Nutr 37 (6): 811-827.

Eisenlord SD, Zak DR. 2010. Simulated atmospheric nitrogen deposition alters actinobacterial community composition in forest soils. Soil Sci Soc Am J 74: 1157-1166.

Ettenauer JD, Pinar G, Lopandic K, Spangl B, Ellersdorfer G, Voitl C, Sterflinger K. 2012. Microbes on building materials-Evaluation of DNA extraction protocols as common basis for molecular analysis. Sci Total Environ 439: 44-53.

Fierer NM, Breitbart M, Nulton J, Salamon P, Lozupone C, Jones R, Robeson M, Edwards RA, Felts B, Rayhawk S, Knight R, Rohwer F, Jackson RB. 2007. Metagenomic and small-subunit rRNA analyses reveal the genetic diversity of bacteria, archaea, fungi, and viruses in soil. Appl Environ Microbiol 73 (21): 7059-7066.

Griffiths RI, Thomson BC, James P, Bell T, Bailey M, Whiteley AS. 2011. The bacterial biogeography of British soils. Environ Microbiol 13 (6): 1642-1654.

Kimura M. 1980. A simple method for estimating evolutionary rates of base substitutions through comparative studies of nucleotide sequences. J Mol Evol 16: 111-120.

Kunito T, Owaki M, Ihyo Y, Sumi H, Toda H, Fukuda D, Park HD. 2012 Genera Burkholderia and Lipomyces are predominantaluminumresistant microorganisms isolated from acidic forest soils using cycloheximide-amended growth media. Ann Microbiol 62: 13391344.

Lee-Cruz L, Edwards DP, Tripathi BM, Adams JM. 2013. The impact of logging and forest conversion to oil palm on soil bacterial communities in Borneo. Appl Environ Microbiol 79 (23): 7290-7297.
Li Y, Chen L, Wen H, Zhou T, Zhang T, Gao X. 2014. 454 pyrosequencing analysis of bacterial diversity revealed by a comparative study of soils from mining subsidence and reclamation areas. J Microbiol Biotechnol 24 (3): 313-323.

Liu Z, Lozupone C, Hamady M, Bushman F, Knight R. 2007. Short pyrosequencing reads suffice for accurate microbial community analysis. Nucleic Acids Res 35: 120-130.

Liu YJ, Liu SJ, Drake HL, Horn MA. 2011. Alphaproteobacteria dominate active 2-methyl-4-chlorophenoxyacetic acid herbicide degraders in agricultural soil and drilosphere. Environ Microbiol 13 (4): 991-1009.

Magurran AE. 2004. Measuring Biological Diversity. Blackwell Publishing, Oxford, UK.

Murdiyarso D, Van Noordwijk M, Wasrin UR, Tomich TP, Gillison AN 2002. Environmental benefits and sustainable land-use options in the Jambi transect, Sumatra. J Veget Sci 13: 429-438.

Quast C, Pruesse E, Yilmaz P, Gerken J, Schweer T, Yarza P, Peplies J, Glockner FO. 2012. The SILVA ribosomal RNA gene database project: improved data processing and web-based tools. Nucleic Acids Res 11 (28): 1-7.

Serkebaeva YM, Kim Y, Liesack W, Dedysh SN. 2013. Pyrosequencingbased assessment of the bacteria diversity in surface and subsurface peat layers of a northern wetland, with focus on poorly studied phyla and candidate divisions. PLoS ONE 8 (5): 63994. DOI: 10.1371/journal.pone.0063994.

Simpson EH. 1949. Measurement of diversity. Nature 163: 688

Spain AM, Krumholz LR, Elshahed MS. 2009. Abundance, composition, diversity and novelty of soil Proteobacteria. ISME J 3: 992-1000.

Stopnisek N, Bodenhausen N, Frey B, Fierer NL, Eberl, Weisskopf L. 2013. Genus-wide acid tolerance accounts for the biogeographical distribution of soil Burkholderia populations. Environ Microbiol 16 (6): 1503-1512.

Tamura K, Stecher G, Peterson D, Filipski A, Kumar S. 2013. MEGA6: Molecular Evolutionary Genetics Analysis version 6.0. Mol Biol Evol 30: 2725-2729.

Tripathi BM, Kim M, Singh D, Lee-Cruz L, Lai-Hoe A, Ainuddin AN, Go R,1 Rahim RA, Husni MHA, Chun J, Adams JM. 2012. Tropical soil bacterial communities in Malaysia: $\mathrm{pH}$ dominates in the equatorial tropics too. Microb Ecol 64: 474-484.

Tripathi BM, Kim M, Lai-Hoe A, Shukor NAA, Rahim RA, Go R, Rahim RA, Go R, Adams JM. 2013. pH dominates variation in tropical soil archaeal diversity and community structure. FEMS Microbiol Ecol 86: 303-311.

Tsiknia M, Paranychianakis NV, Varouchkis EA, Moraetis D, Nikolaidis NP. 2014. Environmental drivers of soil microbial community distribution at the koiliaris critical zone observatory. FEMS Microbiol Ecol 90 (1): 139-152.

Van Reeuwijk LP. 2000. Procedures for soil analysis. Technical paper. International Soil Reference and Information Centre, FAO, Rome.

Wang Q, Garrity G, Tiedje J, Cole J. 2007. Natıve Bayesian classifier for rapid assignment of rRNA sequences into the new bacterial taxonomy. Appl Environ Microbiol 73: 5261-5267.

Wijayanti M, Meryandini A, Wahyudi AT, Yuhana M. 2014. Diversity and the composition of fatty acids of lipolytic bacteria isolated from soil and aquatic sediment in a forest and on an oil palm plantation. Makara J Sci 18 (3): 71-78.

Will C, Thurmer A, Wollherr A, Nacke H, Herold N, Schrumpf M, Gutknecht J, Wubet T, Buscot F, Daniel R. 2010. Horizon specific bacterial community composition of German grassland soils, as revealed by pyrosequencing-based analysis of $16 \mathrm{~S}$ rRNA genes. Appl Environ Microbiol 76: 6751-6759. 